\title{
Arsenic trioxide induces oxidative stress, DNA damage, and mitochondrial pathway of apoptosis in human leukemia $(\mathrm{HL}-60)$ cells
}

\author{
Sanjay Kumar, Clement G Yedjou and Paul B Tchounwou*
}

\begin{abstract}
Background: Acute promyelocytic leukemia (APL) is a subtype of acute myeloid leukemia (AML), which accounts for approximately $10 \%$ of all acute myloid leukemia cases. It is a blood cancer that is formed by chromosomal mutation. Each year in the United States, APL affects about 1,500 patients of all age groups and causes approximately $1.2 \%$ of cancer deaths. Arsenic trioxide (ATO) has been used successfully for treatment of APL patients, and both induction and consolidated therapy have resulted in complete remission. Recently published studies from our laboratory have demonstrated that ATO pharmacology as an anti-leukemic drug is associated with cytotoxic and genotoxic effects in leukemia cells.

Methods: In the present study, we further investigated the detailed molecular mechanism of ATO-mediated intrinsic pathway of apoptosis; using HL-60 cells as a test model. Oxidative stress was assessed by spectrophotometric measurements of MDA and GSH levels while genotoxicity was determined by single cell gel electrophoresis (Comet assay). Apoptosis pathway was analyzed by Western blot analysis of Bax, Bcl2 and caspase 3 expression, as well as immunocytochemistry and confocal imaging of Bax and Cyt c translocation and mitochondrial membrane potential depolarization.
\end{abstract}

Results: ATO significantly $(p<0.05)$ induces oxidative stress, DNA damage, and caspase 3 activityin HL-60 cells in a dose-dependent manner. It also activated the intrinsic pathway of apoptosis by significantly modulating $(p<0.05)$ the expression and translocation of apoptotic molecules and decreasing the mitochondrial membrane potential in leukemia cells.

Conclusion: Taken together, our research demonstrated that ATO induces mitochondrial pathway of apoptosis in $\mathrm{HL}-60$ cells. This apoptotic signaling is modulated via oxidative stress, DNA damage, and change in mitochondrial membrane potential, translocation and upregulation of apoptotic proteins leading programmed cell death.

Keywords: Arsenic trioxide, Oxidative stress, DNA damage, Apoptosis, HL-60 cells

\section{Background}

Acute promyelocytic leukemia (APL) is a subtype of acute myeloid leukemia (AML), which causes approximately $1.2 \%$ of cancer deaths in USA [1,2]. APL is a blood cancer that affects all age groups of people and strikes about 1,500 patients in the United States each year [3]. Initially, APL was treated with conventional chemotherapy method by using cytarabine and daunorubicin to achieve complete

\footnotetext{
* Correspondence: paul.b.tchounwou@jsums.edu

Cellomics and Toxicogenomics Research Laboratory, NIH/NIMHD-RCMI Center for Environmental Health, College of Science, Engineering and Technology, Jackson State University, 1400 Lunch Street, Box18750, Jackson, Mississippi MS39217, USA
}

remissions (CRs) in approximately $70 \%$ of patients having 5 -year disease-free survival of 35-45\% [4,5]. All trans retinoic acid (ATRA) has brought revolutionary change for APL patients treatment. Combination of ATRA plus an anthracycline, with or without cytarabine achieved remission rates of nearly $90 \%$ for APL patients [1]. Although many therapeutic advances such as combined chemotherapy and hematopoietic stem cell transplantation have been made to improve the survival rate of APL patients, a higher proportion of patients relapse and hence do not undergo complete remission. Also, because of the growing evidence of resistance to ATRA treatment of APL patients 
[6], the U.S. Food and Drug Administration (FDA) approved arsenic trioxide (ATO) for APL patient treatment in September 2000 on the basis of several human clinical trials showing very promising results [7].

ATO is a drug of choice for the treatment of both relapsed and refractory APL patients. It is used alone or combination with all trans retinoic acid (ATRA) to achieve complete remission and maximum survival rate $[8,9]$. Existing evidence has shown that APL patients treated with ATO achieved complete remission with high survival rate without ATRA combination [10]. In a Phase II clinical trial study, it was reported that these APL patients treated with ATO alone observed a high rate of 5-years disease free survival (DFS) and an overall survival (OS) [11]. Few reports have suggested that ATO inhibits proliferation of human myeloma cells by cell cycle arrest [12] and induces apoptosis in HL-60 cells by phosphotidylserine externalization as well as DNA laddering [3].

ATO is a clastogenic/genotoxic compound. It has been shown to induce DNA damage/mutation in cultured mouse lymphoma cells [13] and bone marrow cells of SpragueDawley rats [14]. It induces DNA damage through double strands break in human colon cancer cells [15] and also DNA fragmentation as well as p53 activation in gastric cancer cells [16]. ATO also modulates stress gene (p53) expression in human liver carcinoma cells (HepG2) [17].

Although the detailed molecular mechanisms of the anti-cancer potency of ATO are not well understood, it has been shown to induce oxidative stress in hepatocellular carcinoma cells [18] and apoptosis in leukemia as well myeloma cells $[19,20]$. It has also been reported to induce apoptosis in cancer cells through cell cycle arrest [21] and modulation of apoptotic genes expression in NB4 cells [22]. ATO has also been shown to induce mitotic arrest and apoptosis in NB4 cells by changing mitochondrial membrane potential [23]. However, the detailed molecular mechanisms of ATO-induced oxidative stress, genotoxicity, and intrinsic pathway of apoptosis in HL-60 cells are not well elucidated. Therefore, in the present study, we investigated ATO-induced oxidative and genotoxic stress and its resulting impact on specific biomarkers of the mitochondrial pathway of apoptosis inhuman leukemia (HL-60) cells. HL-60 cell line has been derived from peripheral blood leukocytes of a patient with acute promyelocytic leukemia [24].

\section{Methods}

\section{Cell line and culture}

The APL cell line used in this study was HL-60. The Cells were purchased from the American Type Culture Collection (Manassas, VA), and maintained at $37^{\circ} \mathrm{C}$ in an atmosphere of 5\% CO2 and 95\% air according to standard procedures. HL-60 cells were cultured in Iscove's Modified Dulbecco's Medium (IMDM) containing 10\% fetal bovine
Serum (FBS) and 1\% penicillin-streptomycin solution with cell density, $2 \times 10^{5}$ viable cells $/ \mathrm{ml} .5 \times 10^{7}$ cells were seeded for each dose of arsenic trioxide and incubated 24 hour at $37^{\circ} \mathrm{C}$ inside $\mathrm{CO}_{2}$ incubator.

\section{Chemicals and reagents}

ATO was purchased from Fischer Scientific (Pittsburgh, PA). Mitochondrial isolation kit, Caspase assay kit, protease inhibitor and Glutathione assay kit were obtained from Sigma-Aldrich (St. Louis, MO). Anti-Cytochrome C, anti-Bax and anti-Bcl2 were purchased by Cell Signaling Technology (Danvers, MA). Lipid peroxidation kit and caspase 3 kit were obtained from Abcam (Cambridge, MA). Mitotracker red, Hoechst 33342, Alexa fluor 568 and Alexa fluor 568 were purchased from Life Technologies (Grand Island/NY).

\section{Measurement of reduced GSH}

Leukemia cells were grown in presence or absence of ATO and the GSH content inside the cytoplasm was measured following a previously published protocol [25].

\section{Lipid peroxidation assay}

HL-60 cells were treated with or without ATO and lipid peroxidation was evaluated by measuring malondialdehyde (MDA) levels using the lipid peroxidation assay kit (Abcam) as previously described [25].

\section{Single cell gel electrophoresis (Comet) assay}

HL-60 cells were cultured in presence or absence of ATO and DNA damage was analyzed by performing a very sensitive alkaline comet assay as previously described [26], with few modifications in our laboratory $[27,28]$. The whole process was carried out under yellow light in order to minimize UV light damage. Agarose was prepared through melting in a boiling water bath and allowing it to return to room temperature. The cells were mixed with the melted agarose in a 1:10 ratio. Approximately $75 \mu \mathrm{L}$ of the mixture of agarose and cells were placed on comet slides, and the agarose was solidified at $4^{\circ} \mathrm{C}$ for $10 \mathrm{~min}$. After $10 \mathrm{~min}$, the slides were placed in a lysis solution at $4^{\circ} \mathrm{C}$ for $30 \mathrm{~min}$ to lyse the embedded cells in the agarose. The excess lysis solution was removed from the slides and placed in an alkaline solution to denature the DNA for $40 \mathrm{~min}$ at room temperature. Later, the slides were subjected to TBE (Tris borate EDTA buffer) electrophoresis for $10 \mathrm{~min}$ with 1 volt/cm current between the two electrodes. Then the slides were fixed with $70 \%$ ethanol for $5 \mathrm{~min}$, followed by SYBR green staining. The stained slides were examined using an epifluorescent microscope (Olympus BX51 TRF, USA). The data were analyzed with DNA damage analysis software (Loats Associates Inc., USA). The control comet slides were prepared along with the test comet slides under yellow light 


\section{Western blotting analysis}

Western blot analysis was conducted to determine specific cellular responses targeting apoptosis-related proteins including Bax, cyt $\mathrm{C}$ and Bcl-2. HL-60 cells were treated with different doses of ATO for $24 \mathrm{hr}$ at $37^{\circ} \mathrm{C}$. After incubation, cells were washed twice with cold phosphate buffered saline (PBS) and lysed in RIPA buffer containing (1\% Nonidet P-40, 0.5\% sodium deoxycholate, 0.1\% SDS, $100 \mu \mathrm{g} / \mathrm{ml}$ phenylmethylsulfonyl fluoride, $100 \mu \mathrm{g} / \mathrm{ml}$ aprotinin, $1 \mu \mathrm{g} / \mathrm{ml}$ leupeptin, and $1 \mathrm{~mm}$ sodium orthovanadate) on ice $20 \mathrm{~min}$. It was centrifuged at $14000 \mathrm{rpm}$ for $12 \mathrm{~min}$ and supernatant collected in fresh micro centrifuge tubes. The total protein of cells extracts contained in the supernatant was measured by the Bradford method at $595 \mathrm{~nm}$ using a microtiter plate reader [29]. An equal amount $(40 \mu \mathrm{g})$ of protein from control or treated cells was loaded per lane on a 10\% SDS-PAGE gel, transferred into nitrocellulose membrane and analyzed by Western blotting for each specific protein of interest using its specific antibody as described previously [30]. The band intensities were quantified using Image J (National Institutes of Health).

\section{Confocal microscopy for Bax and Cytochrome c translocation}

HL-60 cells $\left(1 \times 10^{6}\right.$ cells) were grown in presence or absence of ATO and further incubated with mitotracker Red CMXRos $(250 \mathrm{nM})$ for $30 \mathrm{~min}$ in dark at $37^{\circ} \mathrm{C}$ to stain mitochondria. After staining, cells were washed twice with PBS and adhered on poly- L- lysine coated chambered slide. Cells were fixed by adding $3 \%$ paraformaldehyde solution and permeabilized with $0.2 \%$ Nonidet P-40 in PBS containing glycine (0.5\%). Cells were blocked in PBS containing 3\% BSA for $30 \mathrm{~min}$, then incubated with cytochrome $\mathrm{C}$ antibody (1:100 dilution) at $4^{\circ} \mathrm{C}$ overnight. Cells were washed with PBS and incubated with Alex fluor 568 tagged secondary Ab (1:1000) for $1 \mathrm{~h}$ at $4^{\circ} \mathrm{C}$ in dark. The cells were then incubated with Hoechst 33342 with (1:1000) for $7 \mathrm{~min}$ in dark to stain the nucleus. The cover slips were then mounted on slides using 90\% glycerol containing $0.025 \%$ PPD as antifade. The images were acquired using the confocal microscope (Olympus Company, Center valley, PA) at appropriate excitation $(578 \mathrm{~nm})$ and emission $(603 \mathrm{~nm})$ wavelengths.

\section{Caspase -3 activity assay}

Caspase- 3 activity was measured in cytosolic fraction of control and ATO-treated HL-60 cells, using commercially available kits and according to manufacturer protocol (Sigma, St. Louis, MO, USA). In brief, cytosolic fraction of cells from both control and ATO treated was prepared as described earlier [31]. Equal amount of cytosolic proteins were used for the assay of caspase 3 activity. Cytosolic protein $(50 \mu \mathrm{g})$ was mixed in a microtiter plate with assay buffer and caspase specific substrates (Ac-DEVD-pNA for caspase-3). After 4-16 $\mathrm{h}$ incubation at $37^{\circ} \mathrm{C}$, the absorbance of pNA released as a result of caspase- 3 like activity was measured at $405 \mathrm{~nm}$ in a microtiter plate reader as described in technical bulletin. The absorbance of negative control (assay buffer substrate) was subtracted from specific values. Mean values of triplicate measurements were presented.

\section{Measurement of change in mitochondrial membrane potential $(\Delta \psi \mathrm{m})$}

The integrity of the inner mitochondrial membrane may be measured by observing the potential gradient across this membrane. This can be achieved by measuring the uptake of the cationic carbocyanine dye, JC1 into the matrix. Mitochondria were isolated from control and ATO-treated HL-60 cells using mitochondria isolation kit (Sigma, St. Louis, MO, USA). Isolated mitochondria were incubated with $2 \mu \mathrm{l} \mathrm{JC1}$ stain (from stock $1 \mathrm{mg} / \mathrm{ml}$ ) and $950 \mu \mathrm{l} \mathrm{JC1}$ assay buffer for $10 \mathrm{~min}$ in dark at $25^{\circ} \mathrm{C}$. The fluorescence of each sample (total assay vol. $1 \mathrm{ml}$ ) was recorded using a Perkin Elmer LS50B spectrofluorometer (excitation $490 \mathrm{~nm}$, slit, $5 \mathrm{~nm}$; emission $590 \mathrm{~nm}$, slit, $7.2 \mathrm{~nm})$ [32].

\section{Immunocytochemistry}

HL-60 cells $\left(1 \times 10^{5}\right)$ were cultured in presence or absence of ATO and placed on poly-L-lysine coated slide. Cells were fixed by using 3\% paraformaldehyde and permeablized with $0.2 \%$ NP-40 containing $0.5 \%$ glycine. After blocking with $4 \%$ BSA, fixed cells were incubated overnight with Ki-67 antibody (dilution, 1:100) (cat\# 33-4711) from life technology company at $4^{\circ} \mathrm{C}$. After incubation, cells were washed with PBS three times and tagged with secondary antibody (anti-mouse fluorescein) for one hour at room temperature followed by Hoechst 33342 (dilution, 1:2000) staining $7 \mathrm{~min}$. Slides were washed with PBS and paste coverslip using prolong gold antifade reagent. After drying, slides were imaged by confocal microscopy (Olympus company, Center valley, PA).

\section{Statistical analysis}

Experiments were performed in triplicates. Data were presented as means \pm SDs. Where appropriate, one-way ANOVA or student paired $t$-test was performed using SAS Softwareavailable in the Biostatistics Core Laboratory at Jackson State University. p-values less than 0.05 were considered statistically significant.

\section{Results}

Arsenic trioxide induces oxidative stress in $\mathrm{HI}-60$ cells In the present study we investigated three biomarkers of oxidative stress including lipid peroxidation as 
characterized by malondialdehyde (MDA) production, cellular GSH content, and DNA damage in HL-60 cells following treatment with different doses of ATO. Interestingly, ATO treatment significantly increased MDA level (Figure 1A) as well as percentages of DNA damage and Comet tail length (Figure 1C-E) in a dosedependent manner. Contrary, a significant decrease in GSH content was observed at higher level of ATO exposure (Figure 1B).
Arsenic trioxide modulates apoptotic proteins expression ATO-induced oxidative stress in HL-60 cells also caused an increase in the expression level of pro-apoptotic proteins (Bax and cytochrome $\mathrm{C}$ ) and reduced the expression level of anti-apoptotic protein (Bcl-2), in a dose-dependent manner (Figure 2A). Densitometric analysis has shown that ATO-induced apoptotic proteins, cytchrome $\mathrm{C}$ and $\mathrm{Bax}$ expression significantly $(p<0.05)$ increased at 4 and $6 \mu \mathrm{g} / \mathrm{ml}$ ATO treated HL-60 cells lysate (2B). Whereas,

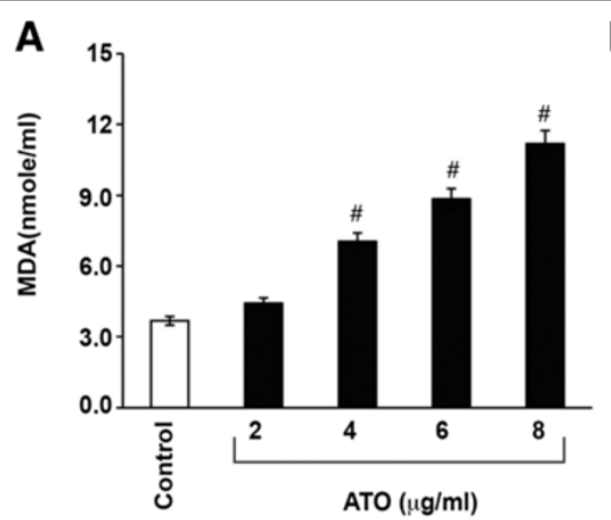

B

C

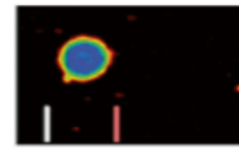

control

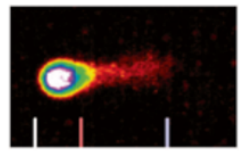

ATO $(6 \mu \mathrm{g} / \mathrm{ml})$

D

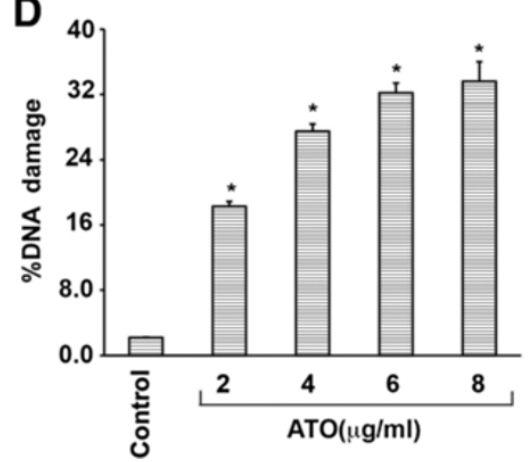

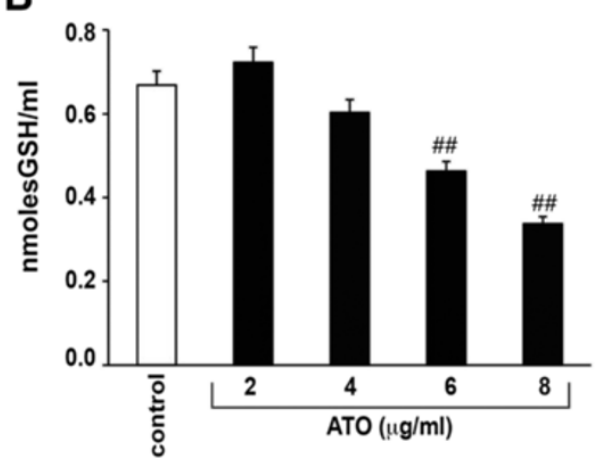

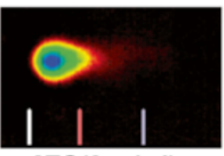

ATO $(2 \mu \mathrm{g} / \mathrm{ml})$

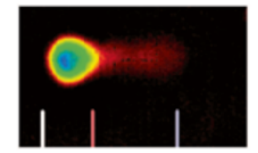

ATO $(8 \mu \mathrm{g} / \mathrm{ml})$

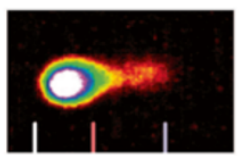

$\operatorname{ATO}(4 \mu \mathrm{g} / \mathrm{ml})$

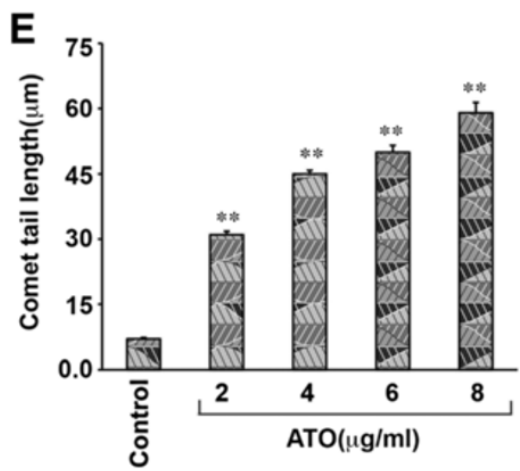

Figure 1 Arsenic trioxide induces oxidative stress in HL-60 cells. (A) HL-60 cells were incubated with 2, 4, 6 and 8 mg/ml of ATO for 24 hrs and the level of malondialdehyde(MDA) was measured by spectrophotometry at $532 \mathrm{~nm}$. MDA was expressed in nmole/ml. Data represent the means of three independent experiments \pm SDs (\# P<0.05). (B) Cells were treated with different doses of ATO for 24 hrs and reduced GSH level was measured by spectrophotometry at $412 \mathrm{~nm}$. GSH was expressed in nmole GSH/ml. Data represent the means of three independent experiments \pm SDs (\#\#P<0.05). (C) HL-60 cells were grown in absence or presence of different doses of ATO for 24 hrs and DNA damage was analyzed by alkaline Comet assay. (D) ATO - induced genotoxicity was expressed as percentage of DNA damage. Data represent the means of three independent experiments \pm SDs (**P $<0.01)$. (E) ATO-induced comet tail length was measured in micrometer. Data represent the means of three independent experiments \pm SDs $(* * * P<0.01)$. 
A

Arsenic Trioxide ( $\mu \mathrm{g} / \mathrm{ml})$

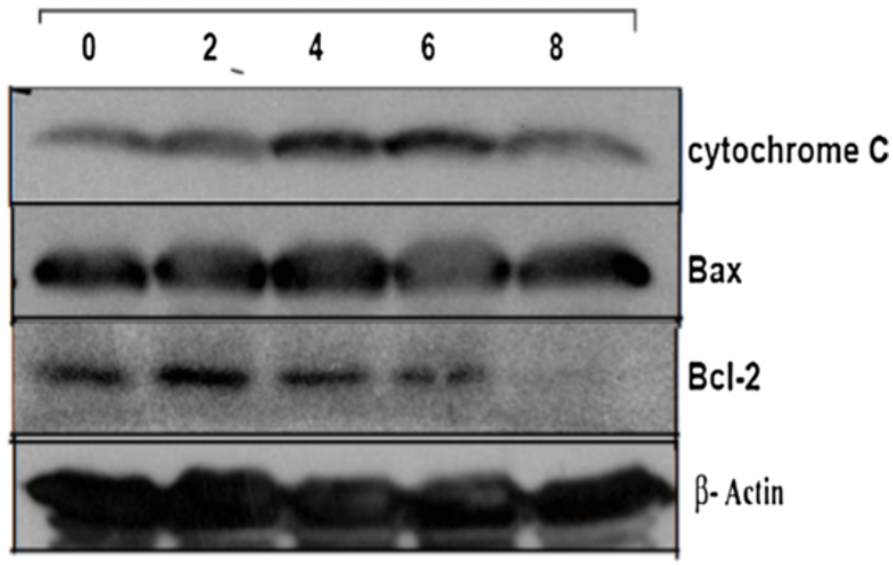

B

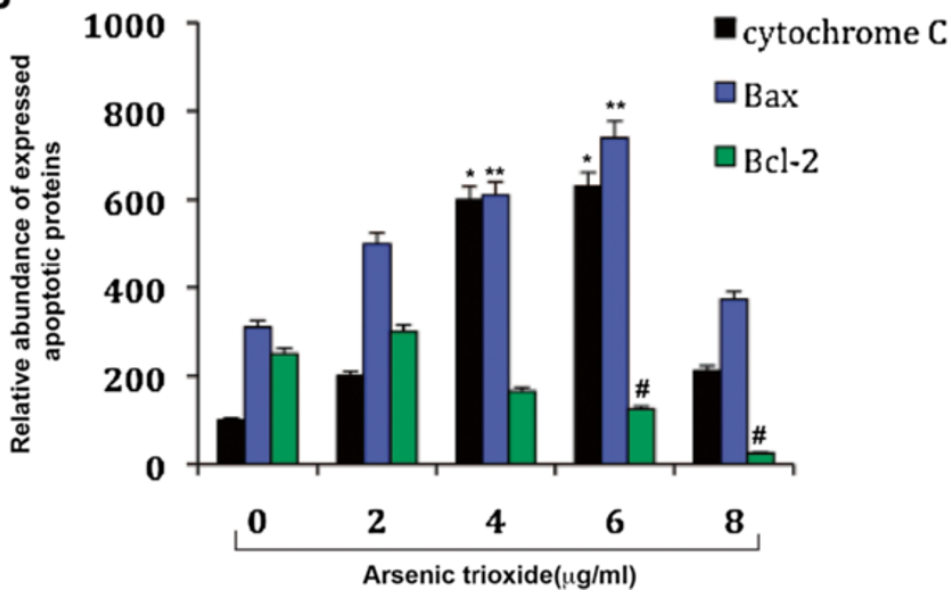

Figure 2 Arsenic trioxide modulates apoptotic proteins expression. (A) Western blots of intrinsic apoptotic pathway proteins in control and ATO-treated HL-60 cells. ATO exposure significantly increased the expression levels of Bax, cytochrome C, and decreased the expression level of $\mathrm{BCl}-2$ in a dose- dependent manner. (B) Densitometric analysis of ATO -induced apoptotic proteins expression in HL-60 cells. Data represent the means of three independent experiments \pm SDs $\left({ }^{*} p<0.01 ;{ }^{* *} p<0.05\right.$ and $\left.\# p<0.01\right)$.

anti-apoptotic protein, Bcl-2 expression was significantly down regulated at 6 and $8 \mu \mathrm{g} / \mathrm{ml}$ ATO treatment cells lysate (2B).

\section{Arsenic trioxide changes inner mitochondrial membrane potential}

Due to imbalance ratio of Bax and Bcl-2 protein expression, ATO treatment lead to change in inner mitochondrial membrane potential and opening of transition pores. We have measured this change in mitochondrial membrane potential after treatment of cells with different doses of ATO and by labeling with very sensitive cationic carbocynine dye, JC-1. In control sample, healthy mitochondria showed high mitochondrial membrane potential $(\psi \mathrm{m})$ with intact membrane and accumulated in their matrix more JC-1 to form J- aggregates, showing intense fluorescence at $590 \mathrm{~nm}$. Whereas in ATO treated cells, mitochondria showed lower $\psi \mathrm{m}$ and less accumulation of JC-1 in their matrix leading to less formation of Jaggregates, and weak fluorescence at $590 \mathrm{~nm}$ (Figure 3A). We have also done confocal microscopy imaging of control and ATO-treated cells followed by staining with JC-1 and DAPI. JC-1 monomer (530 nm) expression was activated by ATO treatment in a dose-dependent manner [Figure 3B (i-v)].

\section{Arsenic trioxide stimulates translocation of Bax and Cytochrome C}

Previous research has reported that oxidative stress activates translocation of pro-apoptotic proteins from cytosol to mitochondria and release of cytochrome $\mathrm{C}$ from mitochondria to cytoplasm inside cell [33]. We have checked ATO-induced translocation of pro-apoptotic protein, Bax from cytosol to mitochondria and cytochrome $\mathrm{C}$ from 


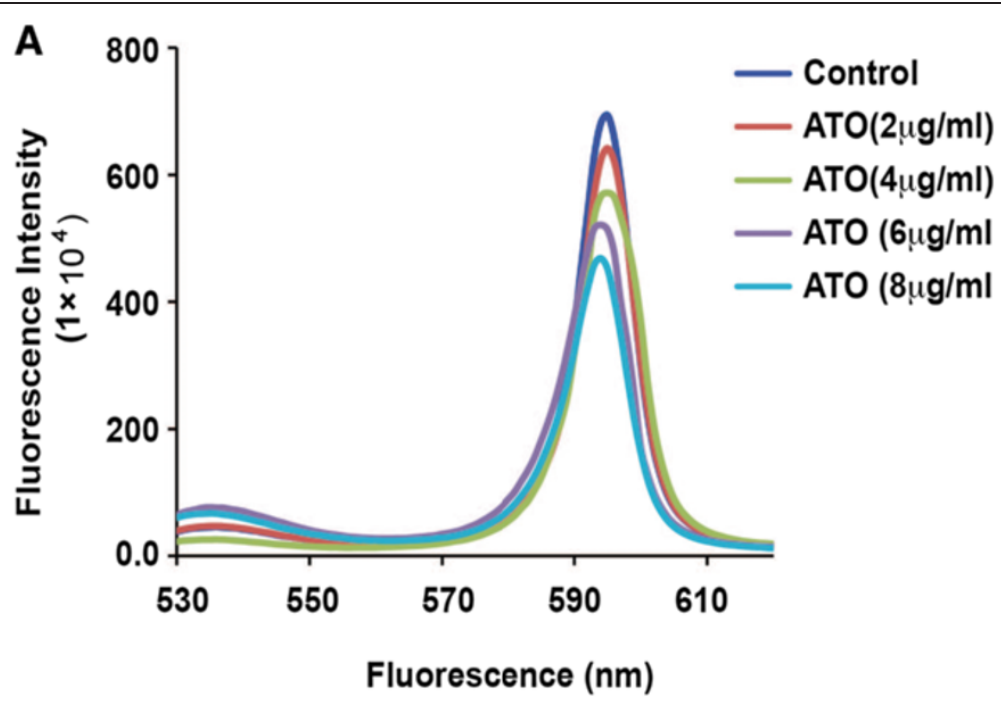

B

(i) Control
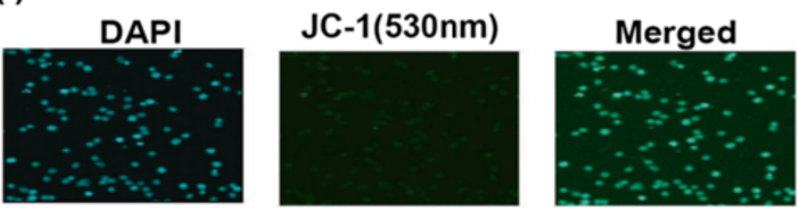

(ii) ATO $(2 \mu \mathrm{g} / \mathrm{ml})$
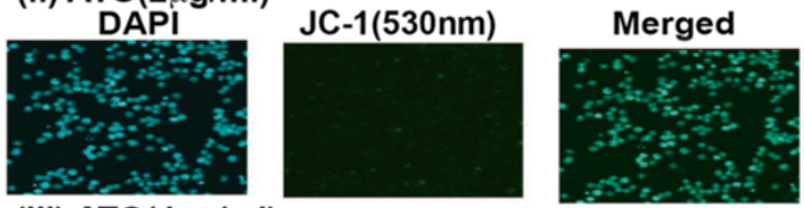

(iii) ATO $(4 \mu \mathrm{g} / \mathrm{ml})$

DAPI

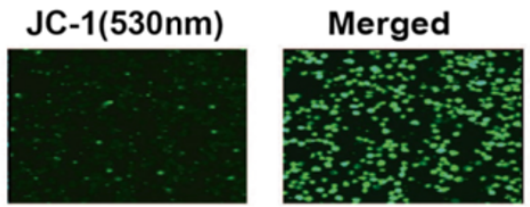

(iv) ATO $(6 \mu \mathrm{g} / \mathrm{ml})$

\section{DAPI}

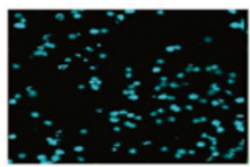

(v) ATO $(8 \mu \mathrm{g} / \mathrm{ml})$
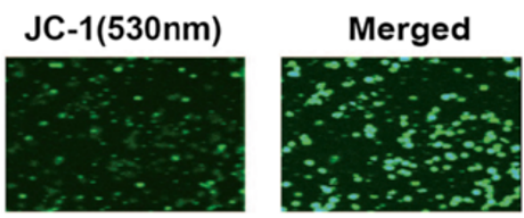
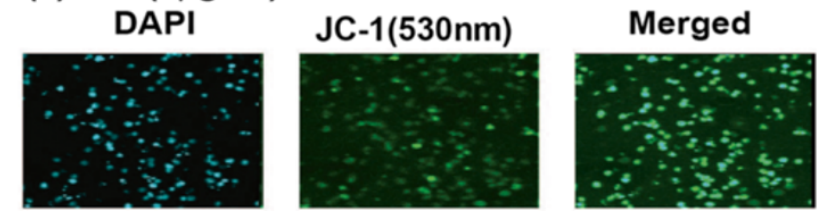

Figure 3 ATO changes mitochondrial membrane potential $(\Delta \psi \mathrm{m})$. (A) ATO treatment was changed the mitochondrial membrane potential in a dose- dependent manner. [(B)(i-v)] There are three subsets of each treatment-DAPI (blue), JC-1 monomer (excitation $530 \mathrm{~nm}$, green) and merged (blue/green). ATO treatment dose-dependently changed mitochondrial membrane potential and opened transition pores. It helped to release J-aggregate and continuously increased JC-1 monomer (green color) in a dose dependent manner in HL-60 cells. 


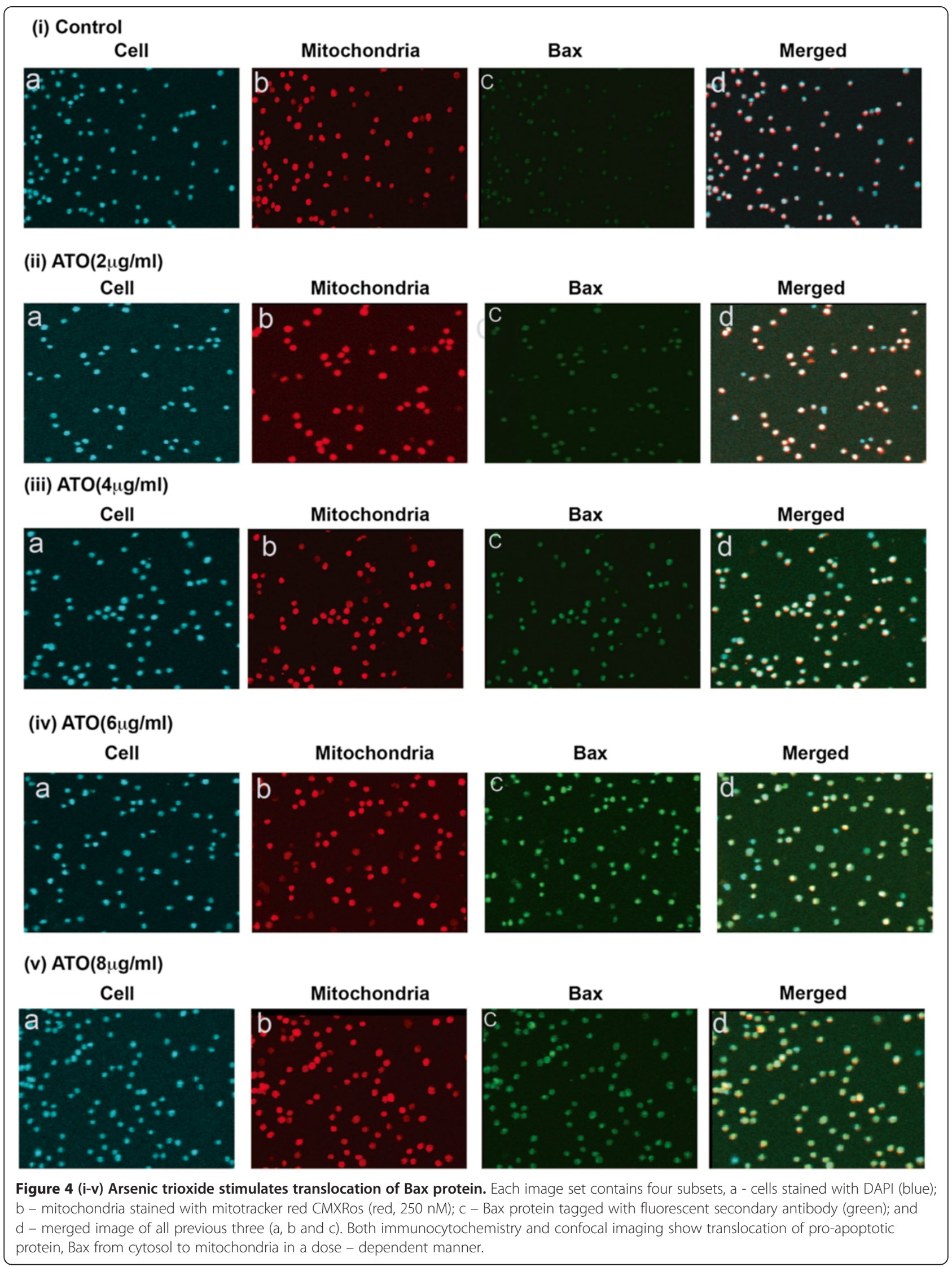



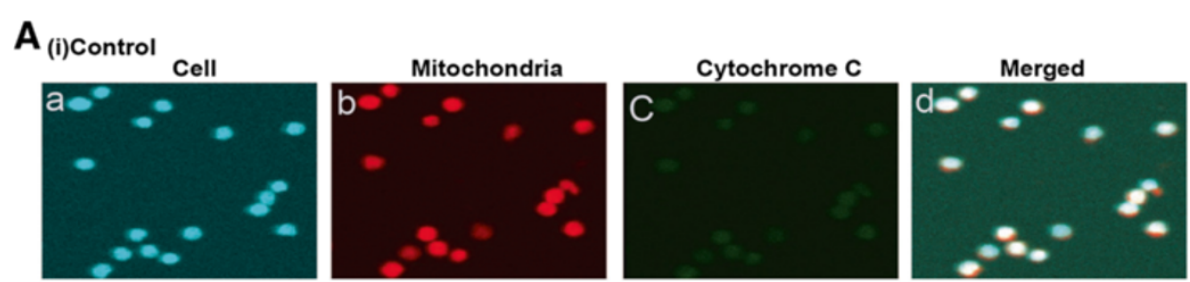

$$
\text { (ii) } \operatorname{ATO}(2 \mu \mathrm{g} / \mathrm{m}
$$
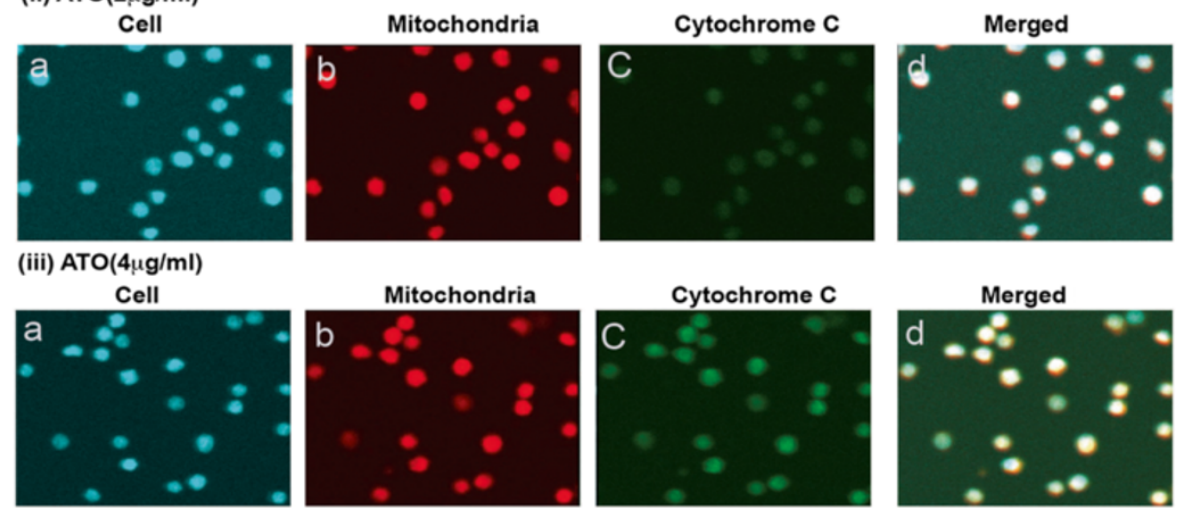

(iv) ATO(6ug/m
Cell

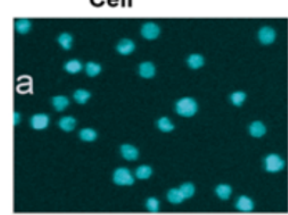

Mitochondria
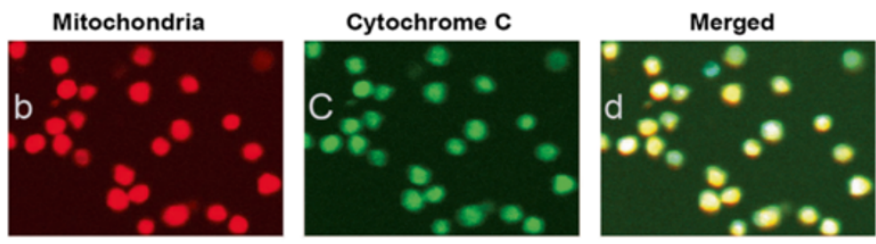

$$
\begin{aligned}
& \text { (v) ATO }(8 \mu \mathrm{g} / \mathrm{ml}) \\
& \text { Cell }
\end{aligned}
$$
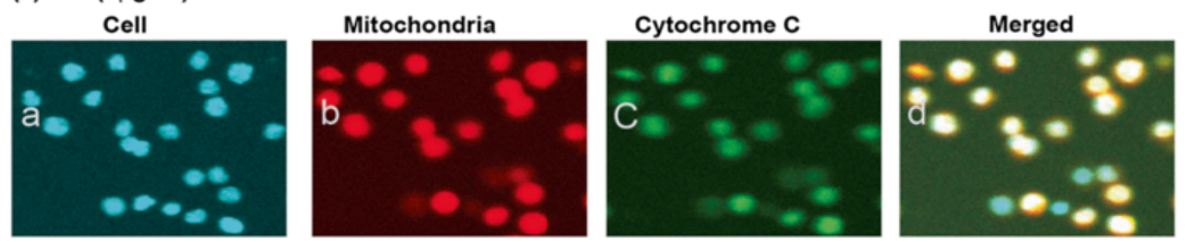

\section{B}

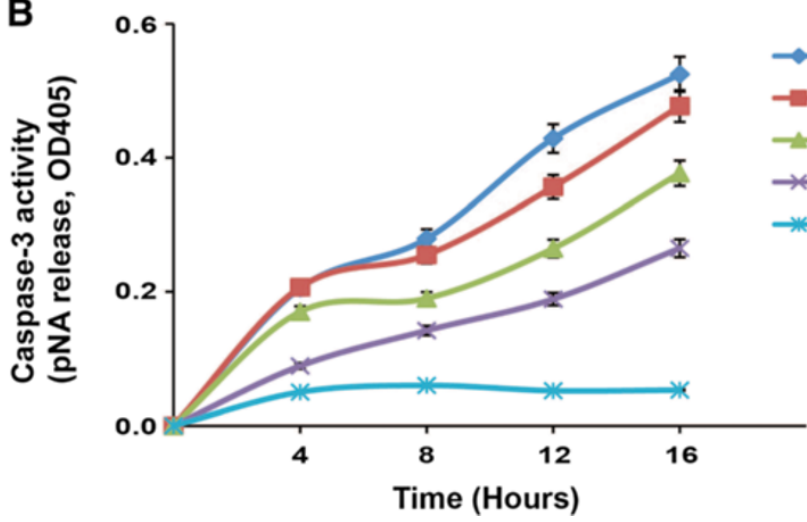

Figure 5 Arsenic trioxide induces release of cytochrome C protein from mitochondria and activation of caspase 3. [(A) (i-v)] Each set contains four subsets, a - cells stained with DAPI (blue); b- mitochondria stained with mitotracker red CMXRos (red, 250nM); C -cytochrome C protein tagged with fluorescent secondary antibody (green); and d - merged image of all previous three (a, b and c). Here, it is shown that cytochrome $\mathrm{C}$ was released from mitochondria in a dose- dependent manner. (B) Data also show a dose-dependent enhancement of caspase 3 activity with the ATO treatment of HL-60 cells. 
mitochondria to cytosol by labeling cells with Hoechst staining, mitochondria with mitotracker red and Bax as well as cytochrome $\mathrm{C}$ protein with green fluorescent antibody. Our results show that the amount of translocated Bax inside mitochondria [Figure $4(\mathrm{i}-\mathrm{v})$ ] and cytochrome C protein in cytosol of ATO treated HL-60 cells increased in a dose-dependent manner [Figure 5A (i-v)]. We used green fluorescent tag anti-Bax and anti-cytochrome $\mathrm{C}$ antibody to recognize translocation of Bax and cytochrome $\mathrm{C}$ by immunocytochemistry and confocal imaging of cells.

\section{Arsenic trioxide stimulates Caspase- 3 activity}

Inside the cytosol, cytochrome $C$ stimulates a series of apoptotic signaling molecules along with variety of caspases (like caspase 9) and finally caspase 3 which is main executioner of mitochondrial pathway of apoptosis [34]. We have investigated the caspase 3 activity in HL-60 cells following treatment with different doses of ATO. Interestingly, ATO upregulatedcaspase 3 activity in a dose-dependent manner (Figure 5B).

\section{Discussion}

Previous studies have reported that ATO diffuses through cell membrane into the cytoplasm and produces cytotoxic effect by generating reactive oxygen species. It has also been reported that ATO causes oxidative stress and cell death in a variety of cells including acute promyelocyte leukemia (APL), acute myeloid leukemia and chronic myeloid leukemia as well as solid tumor cells in vitro [35], but leukemia cells appear to be more susceptible and clinical important than others [36]. Earlier studies have also pointed out that lower doses of ATO induce cell proliferation, while higher doses inhibit growth in NB4 as well as lymphoid malignant cells [21,37]. ATO has also been found to inhibit DNA synthesis in human colon cancer cells [15] and proliferation in myeloma cell lines dose dependent manner [12]. Recently, several groups have provided evidence that ATO induces cell cycle arrest and apoptosis in a variety of leukemia as well as myeloma cells $[12,38]$. But the detailed mechanisms of toxicity to HL-60 cells mostly remain unknown. Here, we have elucidated the molecular mechanisms ATO-induced oxidative stress and intrinsic pathway of apoptosis in HL-60 cells. Our findings indicate that ATO causes oxidative stress through generation of ROS, increase in lipid peroxidation, induction of DNA damage and reduction of GSH level in HL60 cells (Figure 1A-E).

Accumulating data have suggested that ATO - induced apoptosis is associated with down-regulation of $\mathrm{Bcl}-2$ protein in NB4 cells [22] and activation of Bax protein expression as well as reduction of mitochondrial membrane

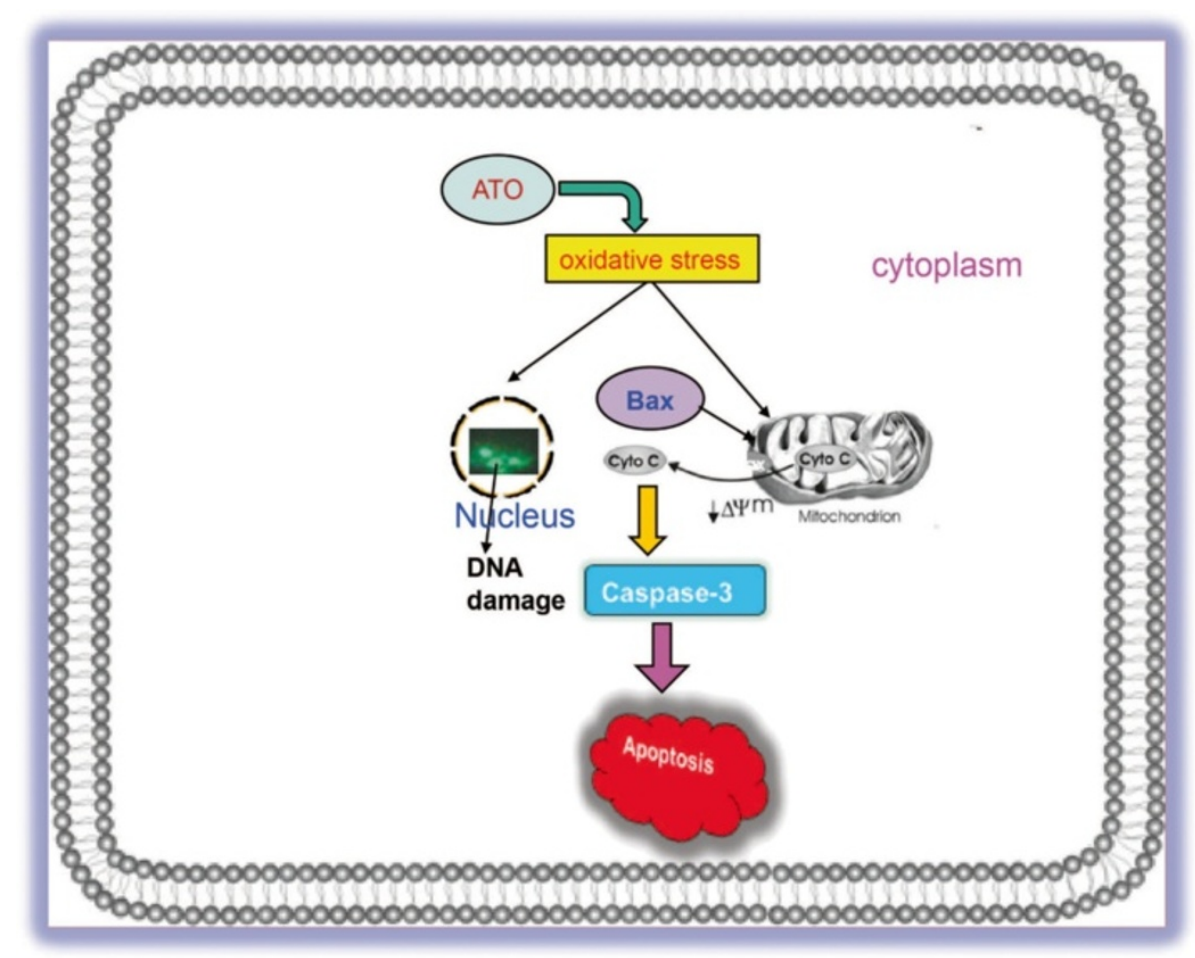

Figure 6 ATO-induced intrinsic pathway of apoptosis in HL-60 cells. ATO induces oxidative stress in APL cells through lipid peroxidation, GSH content changed and DNA damage. It changes mitochondrial membrane potential and modulates expression and translocation of apoptotic proteins, which lead to caspase3 activity and apoptosis in HL-60 cells. 
potential in lymphoma B-cells [39]. Our data presented here reveal that ATO activated Bax and cytochrome $\mathrm{C}$ expression and down-regulated Bcl-2 protein expression in HL-60 cells in a dose-dependent manner (Figure 2A \& B). ATO-induced oxidative stress and alteration of Bax and Bcl-2 proteins expression lead to change in mitochondrial membrane potential of HL-60 cells. In ATOtreated cells, we found that a significant decrease in mitochondrial membrane potential and increase in JC1-monomer (green color) in a dose-dependent manner (Figure 3A-B). It has also been reported from other studies that oxidative stress stimulates translocation of Bax from cytosol to mitochondria and release of cytochrome C inside cytoplasm during liver apoptosis [33]. Other research groups have reported that ATO-induced apoptosis is associated with Bax translocation in cervical cancer cells [40], and release of cytochrome C from mitochondria in lymphoma B-cells [39]. Our results support these findings showing that ATO induces translocation ofBax and cytochrome in HL-60 cells a dosedependent manner [Figure $4(\mathrm{i}-\mathrm{v})$ and $5 \mathrm{~A}(\mathrm{i}-\mathrm{v})$ ]. Inside the cytosol, cytochrome $\mathrm{C}$ seems to activate different signaling molecules along with a variety of caspases and finally caspase 3 in the intrinsic pathway of apoptosis.

Other studies have demonstrated the role of caspase 3 in chemical-induced apoptosis. Cellfood ${ }^{\text {TM }}$ induces apoptosis in leukemia cell lines (U937, Jurkat) through caspase3 activation and DNA fragmentation [41]. Cinnamic acid also causes apoptosis in melanoma cells (HT-144) by caspase-3 activation and DNA damage [42]. Baicalin induces intrinsic pathway of apoptosis in lymphoma cells via DNA fragmentation, modulation of apoptotic and caspase3 proteins expression [43]. Interestingly, we found that ATO treatment increased caspase 3-activity in a dosedependent manner (Figure 4B). ATO as a genotoxic compound induces clastogenic effect in HL-60 cells through oxidative DNA damage and oxidative stress in a dose dependent manner. ATO has been reported to inhibit unscheduled DNA synthesis in V79 Chinese hamster cells by excision of pyrimidine dimmers [44]. Erlotinib, an inhibitor of EGFR enhances ATO mediated DNA double -strand break/damage by preventing EGFR mediated DNA double-strand break repair human A549 lung cancer cells [45]. ATO - induced oxidative stress produces epigenetic effect through specific DNA base modification on exposure of mammalian cells and production of 8-hydroxy-2'-deoxyguanosine (8-OHdG) [46]. It is shown to increase oxidative DNA damage product, 8OHdG in acute promyelocytic leukemia patients during arsenic therapy [47]. ATO causes apoptosis in multiple myeloma cells by disruption of mitochondrial membrane potential and caspase-3 activity [48]. It also induces apoptosis in lymphoid neoplasms through cell cycle arrest $[21,49]$, as well as in plasma cells from myeloma patients
[50]. ATO induces apoptosis in NB4 cells through downregulation of $\mathrm{Bcl}-2$ expression and modulation of PMLRAR $\alpha / P M L$ proteins [22]. Similar to Domoic acid and Okadaic acid (natural toxicants) [51], ATO bears both genotoxic and epigenetic properties. Taken together, we have demonstrated from our research that ATO induces mitochondrial pathway of apoptosis through oxidative stress; modulating expression and translocation of apoptotic proteins, and changing inner mitochondrial membrane potential and caspase 3 activity in HL-60 cells (Figure 6).

\section{Conclusions}

It can be concluded from the present in vitro study that arsenic trioxide induces mitochondrial pathway of apoptosis in HL-60 cells. Although the exact anti-leukemic molecular mechanism of ATO is not well understood, we have investigated in present study its detailed mechanism of oxidative stress-induced intrinsic pathway of apoptosis by modulation of expression and translocation of apoptotic proteins, changing mitochondrial membrane potential and activation of caspase 3 activity in HL-60 cells. By elucidating the anti-leukemic mechanisms of action of ATO in HL-60 cells, we are able to provide new insights into the molecular targets, and a rational basis for drug designing for a more prominent APL chemotherapy in the future.

\section{Abbreviations \\ ANOVA: One way analysis of variance; APL: Acute promyelocytic leukemia; ATO: Arsenictrioxide; ATRA: All trans retinoic acid; DMSO: Dimethylsulfoxide; DNA: Deoxyribonucleic acid; FACS: Fluorescenceactivated cell sorting system; MDA: Malondialdehyde; MTT: 3-(4,5-dimethyl-2-thiazolyl)-2,5-diphenyl- 2tetrazoliumbromide; PBS: Phosphate buffer saline; ROS: Reactive oxygen species.}

\section{Competing interests}

The authors declare that they have no competing interests.

\section{Authors' contributions}

SK and PBT conceived, designed and implemented the study, and drafted the manuscript.CGY participated in the implementation of research activities. All authors read and approved the final draft of the manuscript.

\section{Acknowledgments}

The research described in this publication was made possible by a grant from the National Institutes of Health (Grant No. G12MD007581) through the RCMI Center for Environmental Health at Jackson State University.

Received: 26 March 2014 Accepted: 11 May 2014

Published: 16 May 2014

\section{References}

1. Powell BL: Arsenic trioxide in acute promyelocytic leukemia: potion not poison. Expert Rev Anticancer Ther 2011, 11:1317-1319.

2. Jemal A, Thomas A, Murray T, Thun M: Cancer statistics. CA Cancer J Clin 2002, 52:23-47.

3. Yedjou C, Tchounwou P, Jenkins J, McMurray R: Basic mechanisms of arsenic trioxide (ATO)-induced apoptosis in human leukemia (HL-60) cells. J Hematol Oncol 2010, 3:28-35.

4. Stone RM, Maguire M, Goldberg M: Complete remission in acute promyelocytic leukemia despite persistence of abnormal bone marrow 
promyelocytes during induction therapy: experience in 34 patients. Blood 1988, 71:690-696.

5. Kantarjian HM, Keating MJ, Walters RS: Acute promyelocytic leukemia. M. D. Anderson Hospital experience. Am J Med 1986, 80:789-797.

6. Gallagher RE: Retinoic acid resistance in acute promyelocytic leukemia. Leukemia 2002, 16:1940-1958.

7. Soignet SL, Frankel SR, Douer D: United States multicenter study of arsenic trioxide in relapsed acute promyelocytic leukemia. J Clin Oncol 2001, 19:3852-3860.

8. Lo-Coco F, Avvisati G, Vignetti M, Thiede C, Orlando SM, lacobelli S, Ferrara F, Fazi P, Cicconi L, Di Bona E, Specchia G, Sica S, Divona M, Levis A, Fiedler W, Cerqui E, Breccia M, Fioritoni G, Salih HR, Cazzola M, Melillo L, Carella AM, Brandts $\mathrm{CH}$, Morra E, von Lilienfeld-Toal M, Hertenstein B, Wattad M, Lübbert M, Hänel M, Schmitz N, et al: Retinoic acid and arsenic trioxide for acute promyelocytic leukemia. N Engl J Med 2013, 369:111-121.

9. Soignet SL, Maslak P, Wang ZG, Jhanwar S, Calleja E, Dardashti L, Corso D, DeBlasio A, Gabrilove J, Scheinberg DA, Pandolfi PP, Warrell RP Jr: Complete remission after treatment of acute promyelocytic leukemia with arsenic trioxide. N Engl J Med 1998, 339:1341-1348.

10. Ghavamzadeh A, Alimoghaddam K, Ghaffari SH, Rostami S, Jahani M, Hosseini R, Mossavi A, Baybordi E, Khodabadeh A, Iravani M, Bahar B, Mortazavi Y, Totonchi M, Aghdami N: Treatment of acute promyelocytic leukemia with arsenic trioxide without ATRA and/or chemotherapy. Ann Oncol 2006, 17:131-134.

11. Ghavamzadeh A, Alimoghaddam K, Rostami S, Ghaffari SH, Jahani M, Iravani M, Mousavi SA, Bahar B, Jalili M: Phase II study of single-agent arsenic trioxide for the front-line therapy of acute promyelocytic leukemia. J Clin Oncol 2011, 29:2753-2757.

12. Park WH, Seol JG, Kim ES, Hyun JM, Jung CW, Lee CC, Kim BK, Lee YY: Arsenic trioxide-mediated growth inhibition in MC/CAR myeloma cells via cell cycle arrest in association with induction of cyclin-dependent kinase inhibitor, p21, and apoptosis. Cancer Res 2000, 60:3065-3071.

13. Soriano C, Creus A, Marcos R: Arsenic trioxide mutational spectrum analysis in the mouselymphoma assay. Mutat Res 2008, 646:1-7.

14. Patlolla AK, Tchounwou PB: Cytogenetic evaluation of arsenic trioxide toxicity in Sprague-Dawley rats. Mutat Res 2005, 587:126-133.

15. Stevens JJ, Graham B, Walker AM, Tchounwou PB, Rogers C: The effects of arsenic trioxideon DNA synthesis and genotoxicity in human colon cancer cells. Int J Environ Res Public Health 2010, 7:2018-2032.

16. Jiang $\mathrm{XH}$, Wong $\mathrm{BC}$, Yuen $\mathrm{ST}$, Jiang $\mathrm{SH}$, Cho $\mathrm{CH}$, Lai KC, Lin MC, Kung HF, Lam SK: Arsenic trioxide induces apoptosis in human gastric cancer cells through up-regulation of p53 and activation of caspase-3. Int J Cancer 2001, 91:173-179.

17. Tchounwou PB, Yedjou CG, Dorsey WC: Arsenic trioxide-induced transcriptional activation and expression of stress genes in human liver carcinoma cells (HepG2). Cell Mol Biol (Noisy-le-Grand) 2003, 49:1071-1079.

18. Alarifi S, Ali D, Alkahtani S, Siddiqui MA, Ali BA: Arsenic trioxide-mediated oxidative stress and genotoxicity in human hepatocellular carcinoma cells. Onco Targets Ther 2013, 6:75-84.

19. Wang ZG, Rivi R, Delva L, König A, Scheinberg DA, Gambacorti-Passerini C, Gabrilove JL, Warrell RP Jr, Pandolfi PP: Arsenic trioxide and melarsoprol induce programmed cell death in myeloid leukemia cell lines and function in a PMLand PML-RARa independent manner. Blood 1998, 92:1497-1504.

20. Akao Y, Mizoguchi H, Kojima S, Naoe T, Ohishi N, Yagi K: Arsenic induces apoptosis in B-cell leukemic cell lines in vitro: activation of caspases and down-regulation of Bcl-2 protein. Br J Haematol 1998, 102:1055-1060.

21. Zhang W, Ohnishi K, Shigeno K, Fujisawa S, Naito K, Nakamura S, Takeshita K, Takeshita A, Ohno R: The induction of apoptosis and cell cycle arrest by arsenic trioxide in lymphoid neoplasms. Leukemia 1998, 12:1383-1391.

22. Chen GQ, Zhu J, Shi XG, Ni JH, Zhong HJ, Si GY, Jin XL, Tang W, Li XS, Xong SM, Shen ZX, Sun GL, Ma J, Zhang P, Zhang TD, Gazin C, Naoe T, Chen SJ, Wang ZY, Chen Z: In vitro studies on cellular and molecular mechanisms of arsenic trioxide $\mathrm{As} 2 \mathrm{O} 3$ in the treatment of acute promyelocytic leukemia: As2O3 induces NB4 cell apoptosis with down-regulation of Bcl-2 expression and modulation of PML-RARa/PML proteins. Blood 1996, 88:1052-1061.

23. Cai $X$, Y $U$ Y, Huang $Y$, Zhang L, Jia PM, Zhao Q, Chen Z, Tong JH, Dai W, Chen GQ: Arsenic trioxide-induced mitotic arrest and apoptosis in acute promyelocytic leukemia cells. Leukemia 2003, 17:1333-1337.

24. Collins SJ, Ruscetti FW, Gallagher RE, Gallo RC: Terminal differentiation of human promyelocytic leukemia cells induced by dimethyl sulfoxide and other polar compounds. Proc Natl Acad Sci U S A 1978, 75:2458-2462.
25. Kumar S, Guha M, Choubey V, Maity P, Srivastava SK, Bandyopadhyay U: Bilirubin inhibits Plasmodium falciparum growth through the generation of reactive oxygen species. Free Radic Biol Med 2008, 44:602-613.

26. Singh NP, McCoy MT, Tice RR, Schneider EL: A simple technique for quantitation of low levels of DNA damage in individual cells. Exp Cell Res 1988, 175:184-191

27. Yedjou CG, Tchounwou PB: In-vitro cytotoxic and genotoxic effects of arsenic trioxide on human leukemia (HL-60) cells using the MTT and alkaline single cell gel electrophoresis (Comet) assays. Mol Cell Biochem 2007, 301:123-130.

28. Velma V, Tchounwou PB: Oxidative stress and DNA damage induced by chromium in liver and kidney of goldfish, carassius auratus. Biomark Insights 2013, 8:43-51.

29. Bradford MM: A rapid and sensitive method for the quantitation of microgram quantities of protein utilizing the principle of protein-dye binding. Anal Biochem 1976, 72:248-254.

30. Singh NK, Kundumani-Sridharan V, Kumar S, Verma SK, Kotla S, Mukai H, Heckle MR, Rao GN: Protein kinase N1 is a novel substrate of NFATc1-mediated cyclin D1-CDK6 activity and modulates vascular smooth muscle cell division and migration leading to inward blood vessel wall remodeling. J Biol Chem 2012, 287:36291-36304.

31. Wissing D, Mouritzen $H$, Jaattela M: TNF-induced mitochondrial changes and activation of apoptotic proteases are inhibited by A20. Free Radic Biol Med 1998, 25:57-65.

32. Cossarizza A, Baccarani-Contri M, Kalashnikova G, Franceschi C: A new method for the cytofluorimetric analysis of mitochondrial membrane potential using the Jaggregate forming lipophilic cation 5,5_6,6_-tetrachloro-1,1_3, 3_-tetraethylbenzimidazolcarbocyanine iodide (JC-1). Biochem Biophys Res Commun 1993, 197:40-45

33. Guha M, Kumar S, Choubey V, Maity P, Bandyopadhyay U: Apoptosis in liver during malaria: role of oxidative stress and implication of mitochondrial pathway. FASEB J 2006, 20:1224-1226.

34. Chattopadhyay S, Fensterl V, Zhang Y, Veleeparambil M, Yamashita M, Sen GC: Role of interferon regulatory factor 3-mediated apoptosis in the establishment and maintenance of persistent infection by Sendai virus. J Virol 2013, 87:16-24.

35. Uslu R, Sanli UA, Sezgin C, Karabulut B, Terzioglu E, Omay SB: Arsenic trioxide-mediated cytotoxicity and apoptosis in prostate and ovarian carcinoma cell lines. Clin Cancer Res 2000, 6:4957-4964.

36. Jang M, Kim Y, Won H, Lim S, KRJ, Dashdorj A, Min YH, Kim SY, Shokat KM, Ha J, Kim SS: Carbonyl reductase 1 offers a novel therapeutic target to enhance leukemia treatment by arsenic trioxide. Cancer Res 2012, 72:4214-4224

37. Chen GQ, Shi XG, Tang W, Xiong SM, Zhu J, Cai X, Han ZG, Ni JH, Shi GY, Jia PM, Liu MM, He KL, Ma J, Zhang P, Zhang TD, Paul P, Naoe T, Kitamura K, Miller W, Waxman $\mathrm{S}$, Wang ZY, de The $\mathrm{H}$, Chen SJ, Chen Z: Use of arsenic trioxide $\left(\mathrm{As}_{2} \mathrm{O}_{3}\right)$ in the treatment of acute promyelocytic leukemia (APL): I. $\mathrm{As}_{2} \mathrm{O}_{3}$ exerts dose-dependent dual effects on APL cells. Blood 1997, 89:3345-3353

38. Ma DC, Sun YH, Chang KZ, Ma XF, Huang SL, Bai YH, Kang J, Liu YG, Chu JJ: Selective induction of apoptosis of NB4 cells from $\mathrm{G} 2+\mathrm{M}$ phase by sodium arsenite at lower doses. Eur J Haematol 1998, 61:27-35.

39. Baysan A, Yel L, Gollapudi S, Su H, Gupta S: Arsenic trioxide induces apoptosis via the mitochondrial pathway by upregulating the expression of Bax and Bim in human B cells. Int J Oncol 2007, 30:313-318.

40. Kang YH, Lee SJ: The role of p38 MAPK and JNK in arsenic trioxide-induced mitochondrial cell death in human cervical cancer cells. J Cell Physiol 2008, 217:23-33.

41. Catalani S, Carbonaro V, Palma F, Arshakyan M, Galati R, Nuvoli B, Battistelli S, Canestrari F, Benedetti S: Metabolism modifications and apoptosis induction after Cellfood ${ }^{T M}$ administration to leukemia cell lines. J Exp Clin Cancer Res 2013, 32:63.

42. Niero EL, Machado-Santelli GM: Cinnamic acid induces apoptotic cell death and cytoskeleton disruption in human melanoma cells. J Exp Clin Cancer Res 2013, 32:31.

43. Huang Y, Hu J, Zheng J, Li J, Wei T, Zheng Z, Chen Y: Down-regulation of the PI3K/Akt signaling pathway and induction of apoptosis in CA46 Burkitt lymphoma cells by baicalin. J Exp Clin Cancer Res 2012, 31:48.

44. Okui T, Fujiwara Y: Inhibition of human excision DNA repair by inorganic arsenic and the comutageniceffect in V79 Chinese hamster cells. Mutat Res 1986, 172:69-76. 
45. Kryeziu K, Jungwirth U, Hoda MA, Ferk F, Knasmüller S, Karnthaler-Benbakka C, Kowol CR, Berger W, Heffeter P: Synergistic anticancer activity of arsenic trioxide with erlotinib is based on inhibition of EGFR-mediated DNA double-strand break repair. Mol Cancer Ther 2013, 12:1073-1084.

46. Kessel M, Liu SX, Xu A, Santella R, Hei TK: Arsenic induces oxidative DNA damage in mammalian cells. Mol Cell Biochem 2002, 234-235:301-308.

47. Ninomiya M, Kajiguchi T, Yamamoto K, Kinoshita T, Emi N, Naoe T: Increased oxidative DNA products in patients with acutepromyelocyticleukemia during arsenic therapy. Haematologica 2006, 91:1571-1572

48. Jia P, Chen G, Huang X, Cai X, Yang J, Wang L, Zhou Y, Shen Y, Zhou L, Yu Y, Chen S, Zhang $X$, Wang Z: Arsenic trioxide induces multiple myeloma cell apoptosis via disruption of mitochondrial transmembrane potentials and activation of caspace-3. Chin Med J (Engl) 2001, 114:19-24.

49. Lu M, Levin J, Sulpice E, Sequeira-Le Grand A, Alemany M, Caen JP, Han ZC Effect of arsenic trioxide on viability, proliferation, and apoptosis in human megakaryocytic leukemia cell lines. Exp Hematol 1999, 27:845-852.

50. Rousselot P, Labaume S, Marolleau JP, Larghero J, Noguera MK, Brouet JC, Fermand JP: Arsenic trioxide and melarsoprol induce apoptosis in plasma cell lines and in plasma cellsfrom myeloma patients. Cancer Res 1999, 59:1041-1048.

51. Carvalho PS, Catian R, Moukha S, Matias WG, Creppy EE: Comparative study of domoic acid and okadaic acid induced -chromosomal abnormalities in the CACO-2 Cell Line. Int J Environ Res Public Health 2006, 3:4-10.

doi:10.1186/1756-9966-33-42

Cite this article as: Kumar et al: Arsenic trioxide induces oxidative stress, DNA damage, and mitochondrial pathway of apoptosis in human leukemia (HL-60) cells. Journal of Experimental \& Clinical Cancer Research 2014 33:42

\section{Submit your next manuscript to BioMed Central and take full advantage of:}

- Convenient online submission

- Thorough peer review

- No space constraints or color figure charges

- Immediate publication on acceptance

- Inclusion in PubMed, CAS, Scopus and Google Scholar

- Research which is freely available for redistribution 